Jurnal Health Sains: p-ISSN: 2723-4339 e-ISSN: 2548-1398

Vol. 2, No. 8, Agustus 2021

\title{
PENGARUH MODAL SOSIAL TERHADAP FUNGSI KOGNITIF PADA PASIEN SKIZOFRENIA DI RSUD DR. SOESELO
}

\author{
Glorio Immanuel, Prima Maharani Putri, Irma Finurina Mustikawati \\ Universitas Muhammadiyah Purwokerto (UMP) Jawa Tengah, Indonesia \\ Email: glo_rio@yahoo.com,prima.wijaya55@gmail.com,irmafinurina@gmail.com
}

\begin{tabular}{ll}
\hline INFO ARTIKEL & ABSTRAK \\
\hline Diterima & Penelitian ini ingin melihat hubungan dan pengaruh modal sosial \\
5 Agustus 2021 & terhadap fungs kognitif pada pasien skizofrenia. Modal sosial \\
Direvisi & merupakan suatu konsep yang muncul dari hasil interaksi di dalam \\
15 Agustus 2021 & masyarakat dengan proses yang lama dan diyakini sebagai salah satu \\
Disetujui & komponen utama dalam menggerakkan kebersamaan, mobilitas ide, \\
25 Agustus 2021 & saling kepercayaan dan saling menguntungkan untuk mencapai \\
\hline Kata Kunci: & kemajuan bersama. Interaksi yang membentuk jaringan dalam \\
modal sosial; & kebersamaan pada modal sosial berisi norma, nilai dan pemahaman \\
skizofrenia & bersama yang memfasilitasi kerjasama didalam sebuah kelompok. \\
& Modal sosial secara umum dikaitkan dengan kesehatan dan dianggap \\
& sebagai etiologi penting dalam skizofrenia dimana pada fase awal \\
& skizofrenia terdapat gejala kognitif yang signifikan sehingga sangat sulit \\
& bagi orang-orang dengan gangguan tersebut untuk bekerja, belajar atau \\
& mejalani kehidupan sosial. Metode penelitian ini menggunakan desain \\
& studi potong lintang, dilaksanakan di RS dr. Soeselo dan menggunakan \\
& instrument MMSE. Hasil penelitian terdapat hubungan antara modal \\
& sosial dan gejala kognitif pada pasien skizofrenia dimana pada individu \\
& dengan modal sosial yang baik terbukti dapat menyesuaikan diri lebih \\
& baik dalam fungsi kognitif. Kesimpulan pada individu dengan modal \\
& sosial yang baik dapat menyesuaikan diri dengan lebih baik karena \\
& individu telah memiliki koping, persepsi dan penyesuaian yang lebih \\
& baik tentang diri dan lingkungannya, individu telah memiliki \\
kemampuan untuk menjaga komunikasi dan interaksinya di dalam & kehidupan bermasyarakat.
\end{tabular}

\section{ABSTRACT}

This study wanted to look at the relationship and influence of social capital on cognitive function in schizophrenic patients. Social capital is a concept that arises from the results of interaction in society with a long process and is believed to be one of the main components in driving togetherness, mobility of ideas, mutual trust and mutual benefit to achieve mutual progress. Interactions that form networks in togetherness in social capital contain norms, values and mutual understanding that facilitate cooperation in a group. Social capital is generally associated with health and is considered an important etiology in schizophrenia where in the early stages of schizophrenia there are significant cognitive symptoms making it very difficult for people with the disorder to work, study or work in social life. This research method uses the design of latitude cut study, conducted in dr. hospital. soeselo and using MMSE instruments. The results of the study found a link

How to cite:

E-ISSN:

Published by:
Immanuel, G., Putri, P. M., \& Mustikawati, I. F. (2021) Pengaruh Modal Sosial terhadap Fungsi Kognitif pada Pasien Skizofrenia di RSUD dr. Soeselo. Jurnal Health Sains 2(8). https://doi.org/10.46799/jhs.v2i8.247 $2723-6927$

Ridwan Institute 
between social capital and cognitive symptoms in schizophrenic patients where in individuals with good social capital was shown to better adjust to cognitive function. Conclusions on individuals with good social capital can adjust better because individuals have had better coping,

Keywords: social capital; perception and adjustment about themselves and their environment, skizophrenia individuals already have the ability to maintain their communication and interaction in public life.

\section{Pendahuluan}

World Helath Organitation telah mendefinikan kesehatan dengan tiga elemen, yaitu kesejahteraan fisik, mental dan sosial, ketiga elemen ini sangat erat hubungannya dengan kualitas hidup seorang manusia (Chae et al., 2020). Modal sosial merupakan suatu konsep yang muncul dari hasil interaksi di dalam masyarakat dengan proses yang lama dan diyakini sebagai salah satu komponen utama dalam menggerakkan kebersamaan, mobilitas ide, saling kepercayaan dan saling menguntungkan untuk mencapai kemajuan bersama. Interaksi yang membentuk jaringan dalam kebersamaan pada modal sosial berisi norma, nilai dan pemahaman bersama yang memfasilitasi kerjasama didalam sebuah kelompok (Gujar et al., 2019). Interaksi yang terjadi sesama anggota akan melahirkan modal sosial yang berupa ikatan-ikatan emosional yang menyatukan orang untuk mencapai tujuan bersama, yang kemudian menumbuhkan kepercayaan dan keamanan yang tercipta dari adanya relasi yang relatif panjang.

Dalam konteks pembangunan manusia, modal sosial mempunyai pengaruh yang besar, beberapa dimensi pembangunan manusia sangat dipengaruhi oleh modal sosial antara lain kemampuan untuk menyelesaikan bersama kompleksitas berbagai permasalahan, mendorong perubahan yang cepat di dalam masyarakat, menumbuhkan kesadaran kolektif untuk memperbaiki kualitas hidup dan mencari peluang yang dapat dimanfaatkan untuk kesejahteraan.

Dalam epidemiologi sosial, dikatakan bahwa modal sosial adalah bagian dari hal yang mempengaruhi kesehatan seseorang, hal lainnya adalah jenis kelamin, usia, pendidikan, pekerjaan, kelas sosial, status sosial, posisi dalam hirarki sosial, seperti kondisi kerja, pendapatan absolut wilayah, distribusi pendapatan, kesenjangan pendapatan, perumahan, ketersediaan pangan, eksklusi sosial, isolasi sosial, kebijakan kesehatan tentang penyediaan pelayanan kesehatan dan pembiayaan pelayanan kesehatan (Bhisma, 2010).

Dengan modal sosial seseorang dapat menghadapi tantangan ataupun tuntutan dari pekerjaanya dan juga menyesuaikan diri di dalam usaha-usaha mencari pekerjaan (Astrid et al., 2010). Dengan memiliki modal sosial yang baik, diharapkan setiap individu memiliki koping yang lebih baik dalam hal persepsi, pemahaman diri, dapat mengatasi dan menyesuaikan diri terhadap tekanantekanan yang ada dengan baik termasuk tekanan dari lingkungan. Individu mampu menyesuaikan diri dengan lingkungan, bahasa, cuaca, waktu dan kebiasaankebiasaan baru di tempat yang baru. Kegagalan dalam hal ini dapat menimbulkan keadaan stress, salah satunya adalah kegagalan penyesuaian dan stress yang di sebut "culture shock" (Indrianie, 2012). Kegagalan penyesuaian koping individu terhadap stress akan mempengaruhi baik fungsi maupun struktur hipokampus, beberapa studi menunjukkan korelasi keduanya dan hal ini mengakibatkan skizofrenia (Heim et al., 2004).

Skizofrenia merupakan gangguan jiwa berat yang menimbulkan permasalahan di seluruh dunia, baik di negara maju ataupun negara berkembang. Pada pasien dengan skizofrenia didapatkan gangguan 
perkembangan saraf yang kompleks dengan gangguan fungsi kognitif sebagai fitur utama, yang dikonfirmasi oleh sejumlah penelitian yang telah dilakukan pada pasien yang menderita skizofrenia, dimana terdapat gejala klinis berupa gangguan fungsi sosial pada pasien sebagai konsekuensi dari defisit neurokognitif (Amrein et al., 2016). Permasalahan yang ditimbulkan bukan karena tingkat kematian yang tinggi, tetapi karena gangguan ini menimbulkan hendaya jangka panjang pada penderitanya di dalam melakukan aktifitas sehari-hari termasuk dalam bekerja. Hal ini tentu saja akan menghambat berbagai macam bidang pekerjaan dan juga aktifitas atau hubungan sosial di dalam masyarakat.

Pada fase awal skizofrenia, selain gejala positif dan gejala negatif juga terdapat gejala kognitif yang signifikan sehingga sangat sulit bagi orang-orang dengan gangguan tersebut untuk bekerja, belajar atau mejalani kehidupan sosial. Memahami peran awal masalah kognitif dapat membantu dokter untuk lebih akurat dalam mendiagnosis skizofrenia episode pertama dan dapat mengatakan bahwa gangguan ini terlepas dari gangguan neuropsikiatrik lain yang juga memiliki masalah kognitif. Hal ini juga dapat memungkinkan mereka untuk memberikan pengobatan yang lebih tepat. Menggabungkan tanda-tanda peringatan kognitif skizofrenia dengan riwayat keluarga dan tanda-tanda memburuknya fungsi sehari-hari juga dapat membantu diagnosis dini.

Pasien dapat mengalami gangguan kecepatan proses dalam belajar verbal dan memori, terutama ketika mengkodekan informasi. Dalam periode sebelum gejala muncul dan fase akut pertama, sangat beresiko tinggi terjadinya penurunan IQ dan kemampuan kognitif lainnya. Kombinasi gejala kognitif dan gejala lainnya dapat mendukung di dalam menegakkan diagnosis skizofrenia (Nauert, 2009). Sampai saat ini belum ada terapi spesifik untuk gejala kognitif pada skizofrenia walaupun beberapa antipsikotik atipikal dikatakan dapat memperbaikinya.

Modal sosial secara umum memiliki hubungan dengan kesehatan, namun masih sedikit penelitian yang telah dilakukan untuk mengetahui bagaimana modal sosial dapat mempengaruhi kesehatan (Gujar et al., 2019). Modal sosial telah dianggap etiologi penting dalam skizofrenia, tetapi penelitian mengenai efektivitas modal sosial masih sangat kurang, bukti manfaat modal sosial dibandingkan kelompok kontrol masih sangat sedikit dan diperlukan penelitian lebih lanjut terutama pada populasi tertentu (Kirkbride et al., 2008; Ortega-Flores et al., 2020). Beberapa peneliti mengusulkan agar penelitian di masa depan akan berfokus pada hubungan antara urbanisasi dan perkembangan saraf yang timpang, kemungkinan faktor perlindungan pedesaan (misalnya modal sosial dan perpecahan sosial yang rendah), urbansasi di negara berkembang, variabel budaya dan lokasi geografis, dan asosiasi antara urbanisasi dan gangguan lain (Kothandaraman et al., 2010; Ortega-Flores et al., 2020).

Tujuan penelitian ini adalah Untuk mengetahui hubungan dan pengaruh modal sosial terhadap fungsi kognitif pada pasien skizofrenia.

Manfaat penelitian ini adalah mengetahui hubungan dan pengaruh modal sosial terhadap fungsi kognitif pada pasien skizofrenia.

\section{Metode Penelitian}

Jenis penelitian adalah studi potonglintang (cross-sectional study) yaitu mendeskripsikan penyakit dan paparan pada populasi pada satu titik waktu tertentu. Lokasi penelitian dalah RS dr Soeselo dengan waktu penelitian Desember 2020 - Juli 2021. Subyek penelitian adalah pasien skizofrenia yang baru pertama kali di diagnosa dan berobat di RS dr. Soeselo pada bulan 
Desember 2020 - Mei 2021 dan memenuhi kriteria inklusi dan ekslusi.

Kriteria Inklusi:

1) Usia 18-55 tahun.

2) Pasien skizofrenia yang didiagnosa skizofrenia (ditegakkan berdasarkan kriteria diagnostik PPDGJ III, oleh psikiater).

3) Bersedia menjadi responden.

4) Responden didampingi keluarga.

Kriteria eksklusi:

1) Penderita skizofrenia sesuai kriteria diagnostik PPDGJ III dengan penyakit fisik kronik yang dapat mempengaruhi penilaian skor MMSE.

2) Subjek tidak dapat berkomunikasi sehingga tidak dapat diwawancara.

Sampel penelitian menggunakan

Purposive sampling, yaitu suatu teknik penetapan sampel dengan cara memilih sampel diantara populasi sesuai dengan yang dikehendaki peneliti (tujuan/masalah dalam penelitian), sehingga sampel tersebut dapat mewakili karakteristik populasi yang dikenal sebelumnya (Notoatmodjo, 2010). Jumlah sampel adalah pasien skizofrenia yang memenuhi kiteria inklusi dan berobat di RSUD dr. Soeselo pada bulan Desember 2020 - Mei 2021. Pengambilan dan penentuan jumlah sampel dilakukan dengan teknik sampel konsekutif yaitu semua sampel yang ada dan memenuhi kriteria penelitian dimasukkan dalam penelitian sampai jumlah yang diperlukan terpenuhi.

Variabel penelitian.

1) Variabel bebas (independent variable).

2) Variabel bebas dalam penelitian ini adalah modal sosial.

3) Variabel terikat (dependent variable).

4) Variabel terikat dalam penelitian ini adalah skor MMSE pada pasien skizofrenia.

Definisi operasional.

1) Pasien skizofrenia: pasien dengan gangguan jiwa yang ditegakkan oleh psikiater, menderita skizofrenia dan berobat rawat jalan/ rawat inap di RS dr. Soeselo.

2) Pendidikan umum adalah pendidikan yang mengutamakan perluasan, peningkatan ketrampilan, dan sikap warga belajar dalam bidang tertentu.

3) Simptom Kognitif: Gangguan verbal (kemampuan untuk menghasilkan pembicaraan spontan, inkoheren, asosiasi longgar, neologisme), gangguan serial urutan peristiwa, gangguan dalam kewaspadaan, gangguan eksekutif (atensi, konsentrasi, prioritas dan perilaku sosial).

4) Modal sosial: sumberdaya yang muncul dari hasil interaksi dalam suatu komunitas, baik antar individu maupun institusi yang melahirkan ikatan emosional berupa kepercayaan, hubungan-hubungan timbal balik, dan jaringan-jaringan sosial, nilainilai dan norma-norma yang membentuk struktur masyarakat yang berguna untuk koordinasi dan kerjasama dalam mencapai tujuan bersama.

Parameter modal sosial terdiri atas:

a) Kepercayaan (trust) dinilai dengan: keikutsertaan dalam kelompok yang berdasarkan rasa kepercayaan, yaitu koperasi, arisan.

b) Norma-norma (norms) dinilai dengan: keikutsertaan dalam kelompok keagamaan.

c) Jaringan-jaringan (networks) dinilai dengan: keikutsertaan dalam kelompok sosial.

5) Modal sosial baik: memenuhi seluruh 3 kriteria modal sosial disertai telah menempuh pendidikan minimum Sekolah Menengah Pertama/ pernah mengikuti pendidikan/ pelatihan lain di luar sekolah.

6) Modal sosial buruk: tidak memenuhi kriteria modal sosial baik. 


\section{Hasil dan Pembahasan}

\section{A. Hasil Penelitian}

Telah dilakukan penelitian di RSUD dr Soeselo Slawi pada bulan Desember 2020 - Mei 2021. Penelitian ini bertujuan untuk mengetahui hubungan dan pengaruh modal sosial terhadap fungsi kognitif pada pasien skizofrenia dengan menggunkana instrument MMSE. Sebanyak 34 subjek yang memenuhi kriteria inklusi dan eksklusi dalam studi ini

1. Deskripsi Demografi Pasien

Pada Tabel 1 menunjukkan sebaran demografi subjek menurut jenis kelamin, pendidikan. Jenis kelamin pasien mayoritas adalah wanita dengan jumlah 17 subjek $(53,10 \%)$ dan laki-laki sejumlah 15 subjek (46,90\%). Pendidikan pasien paling banyak adalah SD dengan 17 subjek (53,10\%), SMA dengan 10 subjek $(31,30 \%)$, kemudian Sarjana dengan jumlah 4 subjek $(12,50 \%)$, dan SMP dengan jumlah 1 subjek $(3,10 \%)$. Berdasarkan uji normalitas SaphiroWilk didapatkan nilai $p>0,05$ sehingga distribusi data jenis kelamin, pendidikan adalah normal pada demografi berdasar jenis kelamin dan pendidikan.

Tabel 1

Sebaran Demografi Subjek

\begin{tabular}{cclccc}
\hline No. & Variabel & Kategori & Jumlah & Persentase (\%) & p \\
\hline \multirow{2}{*}{1} & Jenis Kelamin & Laki-laki & 15 & 46,90 & \multirow{2}{*}{0,251} \\
\cline { 3 - 5 } & & Perempuan & 17 & 53,10 & \\
\hline 2 & Pendidikan & SD & 17 & 53,10 & \\
\cline { 3 - 5 } & SMP & 1 & 3,10 & \multirow{2}{*}{0,000} \\
\cline { 2 - 4 } & SMA & 10 & 31,30 & \\
\cline { 2 - 4 } & & Sarjana & 4 & 12,50 & \\
\hline
\end{tabular}

\section{Deskripsi Variabel Usia}

Tabel 2 menunjukkan deskripsi variabel yang diteliti dalam penelitian. Dalam studi yang telah dilakukan, dari 32 subjek rata-rata berusia 32,06 tahun dengan usia termuda 18 tahun dan usia tertua 54 tahun. Berdasarkan uji normalitas Saphiro-Wilk didapatkan nilai $p>0,05$ sehingga distribusi data usia adalah normal.

Tabel 2

Variabel usia

\begin{tabular}{ccccccc}
\hline No. & Kategori & Minimal & Maksimal & $\begin{array}{c}\text { Rata-rata } \\
\text { (tahun) }\end{array}$ & SD & p \\
\hline 1 & Usia & 18 & 54 & 32,06 & 9,19 & 0,251 \\
\hline
\end{tabular}

3. Deskripsi Variabel Modal Sosial dan Fungsi Kognitif

Tabel 3 menunjukkan jumlah sampel subjek yang memenuhi kiteria inklusi dan berobat di RS dr. Soeselo, didapatkan 32 pasien yang memenuhi syarat, kemudian dibagi ke dalam dua kelompok, yaitu kelompok modal sosial baik dan kelompok modal sosial buruk, di dapatkan 14 pasien atau 43.80\% mewakili kelompok modal sosial baik dan 18 pasien atau 56.,30\% mewakili kelompok modal sosial buruk. Dilakukan penilaian skor MMSE pada masing-masing sampel untuk mengetahui fungsi kognitif. 
Pengaruh Modal Sosial terhadap Fungsi Kognitif pada Pasien Skizofrenia di Rsud Dr. Soeselo

Tabel 3

Variabel Modal Sosial dan Fungsi Kognitif

\begin{tabular}{cclcc}
\hline \multirow{2}{*}{ No. } & Variabel & \multicolumn{1}{c}{ Kategori } & Jumlah & Persentase (\%) \\
\hline \multirow{2}{*}{1} & Modal Sosial & Baik & 14 & 43,80 \\
\cline { 3 - 5 } & & Buruk & 18 & 56,30 \\
\hline \multirow{2}{*}{2} & Fungsi & Normal & 15 & 46,90 \\
\cline { 3 - 5 } & Kognitif & Tidak Normal & 17 & 53,10 \\
\hline
\end{tabular}

Berdasarkan tabel 4 didapatkan nilai Skor MMSE seluruh objek maksimal adalah 27 dan minimal adalah 8 , dengan nilai mean 19.19 , median 23,00 dan modus 24,00 dengan standar deviasi adalah 6,388 .
Didapatkan nilai mean skor MMSE pada objek dengan modal sosial baik (22.93) lebih tinggi dari mean skor MMSE pada objek dengan modal sosial buruk (16.28).

Tabel 4

Skor MMSE

\begin{tabular}{cccccccc}
\hline No. & Skor MMSE & Maksimal & Minimal & Mean & Median & Modus & SD \\
\hline 1. & Seluruh Objek & 27 & 8 & 19.19 & 23.00 & 24.00 & 6.388 \\
\hline 2. & Modal Sosial Baik & 27 & 13 & 22.93 & 24.00 & 24.00 & 4.160 \\
\hline 3. & Modal Sosial Buruk & 27 & 8 & 16.28 & 14.00 & 11.00 & 6.378 \\
\hline
\end{tabular}

Berdasarkan tabel 5 didapakan nilai obseverd dan expected untuk cell a, b, c, d masing-masaing adalah 11, 4,3,14 dan nilai expected masing-

Tabel 5

Tabulasi silang antara Modal Sosial dan Fungsi Kognitif

\begin{tabular}{|c|c|c|c|c|c|}
\hline & & & \multicolumn{2}{|c|}{ Modal Sosial } & \multirow{2}{*}{ Total } \\
\hline & & & Baik & Buruk & \\
\hline \multirow[t]{4}{*}{ Fungsi Kognitif } & Normal & Count & 11 & 4 & 15 \\
\hline & & Expected Count & 6.6 & 8.4 & 15.0 \\
\hline & Tidak Normal & Count & 3 & 14 & 17 \\
\hline & & Expected Count & 7.4 & 9.6 & 17.0 \\
\hline \multirow[t]{2}{*}{ Total } & & Count & 14 & 18 & 32 \\
\hline & & Expected Count & 14.0 & 18.0 & 32.0 \\
\hline
\end{tabular}

nilai signifikasi adalah 0,002 , hal ini

masing adalah 6.6, 8.4, 7.4 dan 9.6, menyatakan bahwa table $2 \times 2$ layak untuk di uji dengan Chi-Square.

Tabel 6

Uji Chi-square

\begin{tabular}{lccccc}
\hline & Value & df & $\begin{array}{c}\text { Asymp. Sig. } \\
(\text { 2-sided })\end{array}$ & $\begin{array}{c}\text { Exact Sig. } \\
\text { (2-sided) }\end{array}$ & $\begin{array}{c}\text { Exact Sig. } \\
\text { (1-sided) }\end{array}$ \\
\hline Pearson Chi-Square & $10.041(\mathrm{~b})$ & 1 & .002 & & \\
\hline
\end{tabular}

skor MMSE nya. Berdasarkan demografi

\section{B. Pembahasan}

Sebanyak 32 orang subyek yang sesuai dengan kriteria inklusi telah di ukur di dapatkan 15 orang $(46,90 \%)$ berjenis kelamin laki-laki dan 17 orang $(53,10 \%)$ perempuan, pendidikan SD dengan 17 
subjek $(53,10 \%)$, SMA dengan 10 subjek $(31,30 \%)$, kemudian Sarjana dengan jumlah 4 subjek (12,50\%), dan SMP dengan jumlah 1 subjek $(3,10 \%)$. Sebanyak $14(43,80 \%)$ subyek memiliki modal sosial baik dan $18(56,30 \%)$ subyek dengan modal sosial buruk, didapatkan 15 $(46,90 \%)$ subyek dengan fungsi kognitif normal dan $17(53,10 \%)$ subyek dengan fungsi kognitif tidak normal.

Berdasarkan hasil uji statistik dengan menggunakan SPSS versi 17.0, dimana pada uji normalitas data didapatkan hasil karakteristik sebaran data berdasarkan usia adalah normal, maka dapat disimpulkan bahwa subjek penelitian berasal dari sampel yang setara. Berdasarkan hasil uji Chi-square nilai signifikasi adalah 0,002 , hal ini menyatakan ada hubungan antara modal sosial dan fungsi kognitif.

Pada pasien skizofrenia dengan modal sosial yang baik memiliki rata-rata nilai fungsi kognitif yang lebih baik dibandingkan dengan pasien skizofrenia yang memiliki modal sosial yang buruk, hal ini menunjukkan pasien dengan modal sosial yang baik dapat menyesuaikan diri lebih baik dalam fungsi kognitif, dengan modal sosial individu telah berlatih dan terbiasa untuk berpartisipasi dan mencari jalan bagi keterlibatannya dalam anggota kelompok dan dalam suatu kegiatan masyarakat, dan juga memiliki kemampuan penyesuaian diri yang lebih baik.

\section{Kesimpulan}

Dari penelitian ini di dapatkan bahwa terdapat hubungan antara modal sosial dan fungsi kognitif pada pasien skizofrenia dan didapatkan bahwa pada pasien skizofrenia dengan modal sosial baik memiliki fungsi kognitif yang lebih baik daripada pasien skizofrenia dengan modal sosial yang buruk. Pasien skizofrenia dengan modal sosial yang baik dapat menyesuaikan diri dengan lebih baik karena individu telah memiliki koping (Astrid et al., 2010), persepsi dan penyesuaian yang lebih baik tentang diri dan lingkungannya (Moher et al., 2009), individu telah memiliki kemampuan untuk menjaga komunikasi dan interaksinya di dalam kehidupan bermasyarakat. Modal sosial yang baik dapat menghasilkan koping yang lebih baik dalam hal persepsi, pemahaman diri dan juga meningkatkan kesehatan mental pada penderita skizofrenia. Hal ini membuktikan juga bahwa modal sosial dapat mempengaruhi kesehatan seseorang (Bhisma, 2010).

\section{BIBLIOGRAFI}

Amrein, R., Levitan, M., Freire, R. C. R., \& Nardi, A. E. (2016). Benzodiazepines In Panic Disorder. In Panic Disorder (Pp. 237-253). Springer. Google Scholar

Astrid, M., Krämer, N. C., \& Gratch, J. (2010). How Our Personality Shapes Our Interactions With Virtual Characters-Implications For Research And Development. International Conference On Intelligent Virtual Agents, 208-221. Google Scholar

Bhisma, M. (2010). Desain Dan Ukuran Sampel Untuk Penelitian Kuantitatif Dan Kualitatif Di Bidang Kesehatan. Yogyakarta: Gadjah Mada University Press. Google Scholar

Chae, S., Choi, S., Kim, N., Sung, J., \& Cho, J. (2020). Integration Of Graphite And Silicon Anodes For The Commercialization Of High - Energy Lithium - Ion Batteries. Angewandte Chemie International Edition, 59(1), 110-135. Google Scholar

Gujar, H., Weisenberger, D. J., \& Liang, G. (2019). The Roles Of Human Dna Methyltransferases And Their Isoforms In Shaping The Epigenome. Genes, 10(2), 172. Google Scholar 
Heim, C., Plotsky, P. M., \& Nemeroff, C. B. (2004). Importance Of Studying The Contributions Of Early Adverse Experience To Neurobiological Findings In Depression. Neuropsychopharmacology, 29(4), 641648. Google Scholar

Indrianie, E. (2012). Culture Adjustment Training Untuk Mengatasi Culture Shock Pada Mahasiswa Baru Yang Berasal Dari Luar Jawa Barat. Jurnal Insan, 14, 150-151. Google Scholar

Kirkbride, J. B., Boydell, J., Ploubidis, G. B., Morgan, C., Dazzan, P., Mckenzie, K., Murray, R. M., \& Jones, P. B. (2008). Testing The Association Between The Incidence Of Schizophrenia And Social Capital In An Urban Area. Psychological Medicine, 38(8), 10831094. Google Scholar

Kothandaraman, N., Bajic, V. B., Brendan, P. N. K., Huak, C. Y., Keow, P. B., Razvi, K., Salto-Tellez, M., \& Choolani, M. (2010). E2f5 Status Significantly Improves Malignancy Diagnosis Of Epithelial Ovarian Cancer. Bmc Cancer, 10(1), 1-13. Google Scholar
Moher, D., Liberati, A., Tetzlaff, J., Altman, D. G., \& Group, P. (2009). ReprintPreferred Reporting Items For Systematic Reviews And MetaAnalyses: The Prisma Statement. Physical Therapy, 89(9), 873-880. Google Scholar

Nauert, C. (2009). Desiderius Erasmus. Google Scholar

Notoatmodjo, S. (2010). Ilmu Perilaku Kesehatan. Penerbit Rineka Cipta. Google Scholar

Ortega-Flores, B., Martini, M., Solari, L., Colás, V., Guerrero-Moreno, S., Centeno-Garcia, E., Silva-Romo, G., \& Grajales-Nishimura, M. (2020). Reply To Molina-Garza Et Al.(2019)“Discussion Of: Ortega-Flores Et Al.(2018) Provenance Analysis Of Oligocene Sandstone From The Cerro Pelón Area, Southern Gulf Of Mexico." International Geology Review, 62(4), 421-427. Google Scholar

\section{Copyright holder:}

Glorio Immanuel, Prima Maharani Putri, Irma Finurina Mustikawati (2021)

First publication right:

Jurnal Health Sains

This article is licensed under:

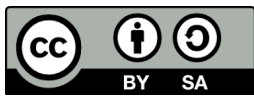

